\title{
KEBIJAKAN PERENCANAAN ANGKUTAN MASSAL DI KOTA BOGOR
}

\author{
Chrisgerson Rudor ${ }^{1}$ \\ Muhammad Findi $A^{2}$ \\ ${ }^{1}$ Mahasiswa Sarjana Ilmu Ekonomi \\ Institut Pertanian Bogor \\ ${ }^{2}$ Dosen Departemen Ilmu Ekonomi \\ Institut Pertanian Bogor
}

Artikel diterima Oktober 2012

Artikel disetujui untuk dipublikasikan Desember 2012

\begin{abstract}
Density and population of bogor that keeps increasing will add the duty of government to provide more public means of mass. Transportation is a vital public facility. Public transport available in Bogor is a city transportation (public transportation) and buses. The existence of a number of public transportation totaling 3,412 units and 30 units of bus has been able to serve the needs of the community in transportation, but in terms of efficiency and comfort are still far from expected.

Based on the results of Stated Preference regression models, we concluded that the most efficient mass transportation is city buses, and the most variable priority attribute passengers on a city bus is the bus occupancy, the bus waiting time efficiency, got a seat, bus convenience and cost/ bus rates. So the recommendation that we can give, the problem due to public transport in bogor can be solved by the means of mass transportation such as city buses.
\end{abstract}

Key words: Density and population of Bogor, PublicTtransportation, Stated Preference Models

\section{ABSTRAK}

Kepadatan dan jumlah penduduk kota Bogor yang terus meningkat akan menambah tugas pemerintah salah satunya adalah menyediakan sarana publik yang lebih bersifat massal. Transportasi merupakan sarana publik yang sangat vital. Transportasi umum yang tersedia di Kota Bogor adalah angkutan kota (angkot) dan bus. Keberadaan angkot yang jumlahnya berjumlah 3.412 unit dan 30 unit bus telah dapat melayani kebutuhan masyarakat dalam bertransportasi tapi dari segi efisiensi dan kenyamanan masih jauh dari yang diharapkan.

Berdasarkan hasil regresi model Stated Preference, diperoleh kesimpulan bahwa angkutan masal yang paling efisien adalah bus kota, dan variabel yang paling diprioritaskan penumpang terhadap atribut bus kota, yaitu okupansi bus, efisiensi waktu tunggu bus, mendapat tempat duduk, kenyamanan bus dan biaya/ tarif. Sehingga rekomendasi yang dapat kami berikan, yaitu masalah kemacetan akibat angkutan umum di Kota Bogor dapat diatasi dengan adanya sarana transportasi massal berupa bus kota.

Kata Kunci : Kepadatan dan Jumlah Penduduk Bogor, Transportasi Umum, Model Stated Preference 


\section{PENDAHULUAN}

Perkembangan Kota Bogor dari tahun ke tahun menunjukkan perubahan yang cukup signifikan baik dari aspek pemetaan kota, pembangunan sektor-sektor jasa bahkan pertumbuhan penduduknya. Pada tahun 2010 jumlahnya mencapai 949.000 jiwa dan kepadatan penduduk Kota Bogor sebesar 440 orang per kilometer persegi dengan meninjau luas Kota Bogor hanya $21,56 \mathrm{~km}^{2}$ yang terdiri atas enam kecamatan, yang dibagi lagi atas sejumlah 68 kelurahan.

Kepadatan dan jumlah penduduk yang terus meningkat akan menambah tugas pemerintah salah satunya adalah menyediakan sarana publik yang lebih bersifat massal. Transportasi merupakan sarana publik yang sangat vital, di Kota Bogor transportasi umum yang tersedia adalah angkutan kota (angkot) dan bus. Keberadaan angkot yang jumlahnya berjumlah 3.412 unit dan 30 unit bus telah dapat melayani kebutuhan masyarakat dalam bertransportasi tapi dari segi efisiensi dan kenyamanan masih jauh dari yang diharapkan.

Masalah transportasi di Kota Bogor dapat diklasifikasikan sebagai berikut:

1. Rasio luas jaringan yang tersedia berbanding luas wilayahnya baru mencapai 5\% dari ketentuan 25\%.

2. Pertumbuhan kendaraan sebesar 7,51\%/tahun.

3. Pertumbuhan penduduk sebesar 3,5\%/tahun.

4. Pertumbuhan PDRB sebesar 5,89\%/tahun.

5. Pertumbuhan bangkitan sebesar $100 \% /$ tahun.

Angkot pun masuk ke dalam daftar angkutan umum yang tidak efisien karena terlalu banyak jenis angkot, jenisnya yang kurang massal (tidak bisa membawa penumpang lebih dari 20 orang), trayek angkot yang tidak efektif sehingga terjadi overlap trayek dimana satu jalan bisa dilewati oleh lebih dari empat jenis angkot (contohnya pada Jalan Ir. H. Juanda di sekitar Kebun Raya Bogor). Jumlah angkutan umum penumpang yang secara legal beroperasi di Kota Bogor merupakan angkutan yang berdaya angkut 14 penumpang.

Kerumitan dalam transportasi publik bukan hanya menjadi masalah pemerintah, operator, melainkan juga masyarakat. Fenomena yang muncul akhirakhir ini mengedepankan wajah transportasi publik yang kurang memberikan kenyamanan, keamanan dan keterjangkauan serta masih mencerminkan biaya sosial dan ekonomi tinggi. Hal ini berakibat pada peminggiran masyarakat secara tidak langsung untuk melakukan mobilitasnya.Wujud nyata pemerintah Kota Bogor yang perlu diapresiasi adalah adanya bus Transpakuan yang merupakan angkutan massal di Bogor semacam bus way dan upaya pengurangan angkot yang dilakukan sejak 2010 diberlakukan sistem shift angkot dan pembatasan izin perpanjangan trayek, namun kebijakan tersebut belum efektif

Oleh karena itu, dibutuhkan suatu skema yang menyeluruh tentang transportasi Kota Bogor agar dapat menyentuh masyarakat. Maka sistem transportasi berkelanjutan diharapkan dapat melengkapi solusi transportasi di Bogor. Sistem transportasi berkelanjutan lebih mudah terwujud pada sistem transportasi yang berbasis pada penggunaan angkutan umum dibandingkan dengan sistem yang berbasis pada penggunaan kendaraan pribadi. Sistem transportasi berkelanjutan merupakan tatanan baru sistem transportasi di era globalisasi saat ini.

\section{MATERI DAN METODE}

\section{Teori Barang Publik}

Barang publik adalah barang dan jasa yang tidak dapat disediakan oleh sistem pasar atau sektor swasta, dimana secara ekonomis pengecualian dapat dilaksanakan akan tetapi biaya untuk mengecualikan segolongan masyarakat dari manfaat suatu barang sangat besar dibandingkan dengan biayanya. Tetapi barang publik juga dapat dihasilkan oleh 
perusahaan swasta atau oleh perusahaan negara.

Salah satu barang publik yang dibutuhkan oleh masyarakat sehari-hari adalah transportasi publik, Transportasi publik memiliki makna jaringan kendaraan umum untuk publik dengan rute yang telah ditentukan dan biasanya memiliki jadwal dan harga yang telah ditentukan (Encarta Dictionary). Transportasi publik mempunyai jalur dan rute yang sudah ditentukan, harga yang tetap dan memiliki halte tertentu. Umumnya transportasi publik juga memiliki jadwal yang sudah ditentukan.

\section{Teori Lokasi}

Ilmu yang menyelidiki tata ruang (spatial order) kegiatan ekonomi, atau ilmu yang menyelidiki alokasi geografis dari sumber-sumber yang potensial serta hubungan-nya dengan atau pengaruh-nya terhadap keberadaan berbagai macam usaha atau kegiatan lain, baik ekonomi maupun sosial (Tarigan, 2006:77). Teori lokasi mempelajari pengaruh jarak terhadap intensitas orang bepergian dari satu lokasi ke lokasi lainnya. Analisis pengaruh jarak terhadap intensitas orang dapat dikembangkan untuk melihat suatu lokasi yang memiliki daya tarik terhadap batas wilayah pengaruhnya, dimana orang masih ingin mendatangi pusat yang memiliki daya tarik tersebut. Hal tersebut terkait dengan besarnya daya tarik pada pusat tersebut dan jarak antara lokasi dengan pusat tersebut.

Salah satu faktor yang menentukan suatu lokasi menarik untuk dikunjungi atau tidak adalah tingkat aksesibilitas. Tingkat aksesibilitas atau tingkat kemudahan untuk mencapai suatu lokasi ditinjau dari lokasi lain di sekitarnya (Tarigan, 2006:78). Tingkat aksesibilitas dipengaruhi oleh jarak, kondisi prasarana perhubungan, ketersediaan berbagai sarana penghubung termasuk frekuensinya dan tingkat keamanan serta kenyamanan untuk melalui jalur tersebut. (Tarigan, 2006:78). Dalam analisis kota yang telah ada atau rencana kota, dikenal standar lokasi (standard for location requirement) atau standar jarak (Jayadinata, 1999:160).

\section{Teori \\ Berkelanjutan}

Transportasi

Definisi world bank (1996) menyatakan secara konseptual, sustainable transportation adalah transportasi yang melayani tujuan utama sebagai penggerak ekonomi wilayah perkotaan dan perkembangan sosial. Poin penting dalam sustainable transportation, yaitu:

Kegiatan transportasi yang
mengutamakan keselamatan dan kenyaman pemakai atau masyarakat. Hal ini mengingat jalan ataupun infrastruktur transportasi lainnya dibuat untuk manusia bukan untuk kendaraan. Jadi kenyamanan manusia umum harus diutamakan.

b. Semua kegiatan transportasi harus dilakukan secara efisien dan efektif baik untuk pemakai kendarannya ataupun bahan bakar yang digunakan. Selama ini kendaraan pribadi rata-rata setiap harinya hanya berisi satu orang. Jadi jika satu orang itu dialihkan untuk menggunakan kendaraan umum, maka bisa dibayangkan berapa banyak bahan bakar yang akan tersimpan dan berapa banyak kemacetan dan emisi kendaraan yang akan berkurang.

c. Tiga pilar penting transportasi, yaitu ekologi, ekonomi dan sosial harus seimbang. Kegiatan transportasi dalam konsep sustainable transportation harus bisa menyeimbangkan semua aspek tersebut.

d. Trasnportasi bukan hanya bisa dinikmati masa sekarang, namun juga untuk masa yang akan datang.

e. Penggunaan transportasi yang ramah lingkungan.

Dalam penelitian ini metode yang akan digunakan penulis untuk memperoleh dan menganalisis data adalah sebagai berikut :

Penelitian Kepustakaan (Library
Research)
Penelitian kepustakaan dilakukan
dengan cara mengumpulkan, membaca,


dan menelaah berbagai peraturan perundang-undangan, literatur, artikel, dan bahan-bahan kuliah yang mempunyai relevansi dengan permasalahan yang dibahas baik yang berasal dari buku maupun internet.

\section{Metode Kuantitatif}

Data-data kuantitatif yang diperoleh dari lembaga terkait dan survey akan diolah dengan menerapkan perhitungan matematis yaitu berupa model Stated Preference. Model Stated Preference adalah metode untuk mendapatkan data tentang keputusan pelaku perjalanan.

Model Stated Preference mendasarkan pada konsep indirect utility (utilitas tidak langsung). Nilai utilitas dapat diketahui dengan melakukan pengukuran terhadap atribut-atribut suatu produk yang diprediksikan memberikan nilai kepuasan terhadap produk tersebut . Parikesit (1993) menyatakan bahwa bentuk umum utilitas suatu produk adalah merupakan model linier yang merupakan kombinasi dari berbagai atribut:

$$
\begin{aligned}
& U_{i}=a_{0}+a_{1} x_{1}+a_{2} x_{2}+\ldots \ldots+a_{n} x_{n} \\
& \text { Keterangan: } \\
& \begin{array}{ll}
\mathrm{U}_{\mathrm{i}} & : \text { utilitas pelayanan produk } \mathrm{i} \\
\mathrm{x}_{1} \ldots \mathrm{x}_{\mathrm{n}} & : \text { atribut produk } \mathrm{i} \\
\mathrm{a}_{1} \ldots \mathrm{a}_{\mathrm{n}} & : \text { koefisien produk } \mathrm{i} \\
\mathrm{a}_{0} & : \text { konstanta }
\end{array}
\end{aligned}
$$

Pemilihan teknik analisis yang sesuai untuk analisis data Stated Preference tergantung pada jenis respon yang diperoleh dari pelaksanaan survey yang dapat berupa data ranking. Skala rating atau pilihan dari beberapa alternatif yang ditawarkan. Pada penelitian ini teknik analisis yang digunakan adalah Regression Approaches.

\section{Penelitian Lapangan (field research)}

Metode lapangan terdiri dari dua metode, yaitu:

a. Metode Wawancara, yaitu dengan cara wawancara langsung dengan narasumber yang kompeten di bidang transportasi publik dan berhubungan dengan data yang diolah seperti DLLAJ Kota Bogor,
Dinas Tata Ruang dan Wilayah Kota Bogor dan Dinas Sosial, Tenaga Kerja dan Transmigrasi Kota Bogor.

b. Metode Survey, yaitu dengan cara mengisi kuesioner di lapangan untuk mendapatkan data dari variabel-variabel yang akan diolah dalam metode stated preference. Adapun variabel-variabel yang akan disurvey adalah biaya, kenyamanan kendaraan, okupansi bus, lama perjalanan, waktu tunggu bus, mendapat tempat duduk, perilaku operator bus, risiko kecelakaan, waktu berjalan kaki, penggunaan waktu alternatif,tarif, dan moda image.

Kriteria responden yang digunakan dalam penelitian ini adalah:

a. Penduduk Kota Bogor atau bukan tetapi melakukan aktivitas kesehariannya di wilayah Kota Bogor.

b. Menggunakan angkutan umum sebagai sarana angkutan.

c. Mengisi kuisioner dengan lengkap.

d. Tanggapan resnponden konsisten sesuai dengan logika stated preference.

\section{Jenis dan Metode Pengumpulan Data}

Data yang dipakai dalam penelitian ini merupakan data primer. Data yang dikumpulkan oleh peneliti yang diperoleh dari para responden yang tersebar di Kota Bogor terutama jalur-jalur angkutan bus umum dalam hal ini penumpang bus. Metode yang digunakan merupakan metode survei terhadap 50 responden. Penelitian ini menggunakan instrumen kuesioner.

\section{HASIL DAN PEMBAHASAN}

Berdasarkan data yang terhimpun, Kota Bogor memiliki beberapa jenis jalan berdasarkan pemeliharaannya, sebagai berikut:

a. Jalan Nasional sepanjang 26.759 $\mathrm{km}$. 
b. Jalan Provinsi sepanjang 26.759 $\mathrm{km}$.

c. Jalan Kota sepanjang $212.704 \mathrm{~km}$ (belum termasuk jalan lingkungan di perumahan yang baru dibangun). Jumlah angkot di Kota Bogor sebanyak 3.412 unit pada tahun 2010 dengan 24 trayek yang disediakan. Jumlah ini telah mengalami penurunan dibandingkan tahun 2003.

Transportasi publik di Kota Bogor sangat didominasi oleh angkutan kota (angkot). Dengan kapasitas maksimum hanya dua belas tempat duduk penumpang, maka angkot belum memenuhi kriteria angkutan massal. Sehingga angkot seringkali menimbulkan berbagai masalah terutama dampaknya bagi kelancaran lalu lintas (kemacetan), efisiensi pelayanan yang rendah, kenyamanan yang minim, sampai dengan masalah sosial.

Angkot juga selalu berhenti untuk menaikkan dan menurunkan penumpang di sembarang tempat sesuai permintaan penumpang. Ini barangkali terdengar ideal, namun pengusaha angkot menghadapi penurunan jumlah penumpang dan pendapatan. Strategi berkendara perlahan untuk memaksimalkan jumlah penumpang yang masuk angkot dan mengebut untuk mengambil penumpang sangat baik untuk memaksimalkan pendapatan dalam jangka waktu pendek, namun berkontribusi pada terjadinya kemacetan. Penumpang yang tidak puas semakin memilih untuk melakukan perjalanan dengan sepeda motor sehingga menambah kemacetan.

Tabel 1. Rekapitulasi Jumlah Angkutan Umum di Kota Bogor Berdasarkan Jenis Pelayanan

\begin{tabular}{|c|c|c|c|c|}
\hline No. & $\begin{array}{c}\text { Jenis Pelayanan } \\
\text { Umum }\end{array}$ & Jenis Kendaraan & $\begin{array}{l}\text { Jumlah } \\
\text { Trayek }\end{array}$ & $\begin{array}{c}\text { Jumlah } \\
\text { Kendaraan }\end{array}$ \\
\hline 1 & AKAP & $\begin{array}{l}\text { Bis } \\
\text { Mikro Bis }\end{array}$ & 172 & 1.837 \\
\hline 2 & AKDP & $\begin{array}{l}\text { Bis } \\
\text { Mikro bis }\end{array}$ & 40 & 330 \\
\hline & & MPU & 10 & 4.827 \\
\hline 3 & Angkutan Kota & MPU & 22 & 3.506 \\
\hline 4 & Pariwisata & $\begin{array}{l}\text { Bis } \\
\text { Mikro bis }\end{array}$ & & $\begin{array}{c}48 \\
4\end{array}$ \\
\hline
\end{tabular}

Keterangan: AKAP : Antar Kota Antar Propinsi

AKDP : Antar Kota Dalam Propinsi

MPU : Mobil Penumpang Umum

Sumber: DLLAJ Kota Bogor, 2005.

Oleh karena itu, salah satu usaha yang perlu dilakukan adalah mengkonversi angkot secara bertahap dan perlahan menjadi bus sedang dan bus besar sesuai dengan time frame yang direkomendasikan. Hal ini untuk menghindari terjadinya perlawanan dari operator angkutan kota yang dapat berakibat pada pemogokan dan anarki. Adapun trayek angkot yang dikonversi hanya pada jalur yang padat dan sibuk ataupun untuk jalur-jalur yang terjadi overlapping trayek, misalnya jalur lingkar Kebun Raya Bogor.

Berdasarkan data konsumsi BBMnya, kita dapat membandingkan efisiensi dari setiap moda transportasi umum. Seperti disajikan pada Gambar 5.1 di bawah ini. 


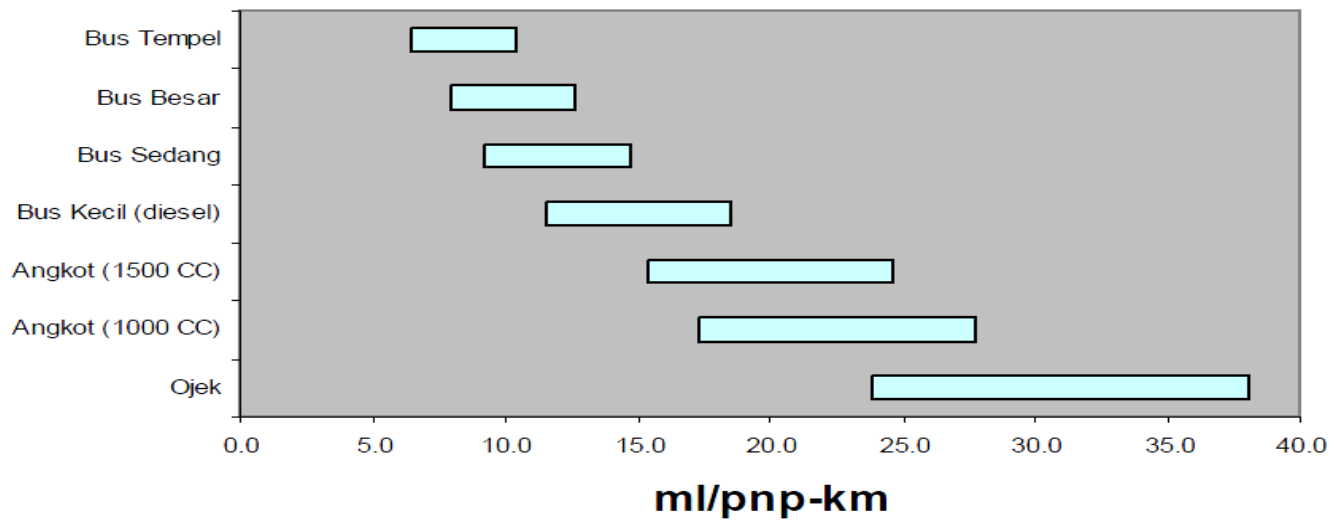

Keterangan: $\mathrm{ml} / \mathrm{pnp}-\mathrm{km}$ = tingkat konsumsi bahan bakar minyak penumpang per kilometer Sumber: Departemen Perhubungan Direktorat Jenderal Perhubungan Darat (2005)

\section{Gambar 5.1 Grafik Konsumsi Bahan Bakar Minyak (BBM) Angkutan Umum}

Untuk konsumsi bahan bakar minyak menurut berbagai jenis dan ukuran kendaraan angkutan, terlihat bahwa semakin besar kendaraannya semakin kecil tingkat konsumsinya per penumpang kilometer. Sehingga penggunaan bus lebih efisien dibandingkan dengan penggunaan angkutan kota (angkot $1000 \mathrm{cc}$ dan 1500 cc).

Untuk mewujudkan sistem transportasi umum yang ideal dan berkelanjutan di Kota Bogor diperlukan penelitian lebih lanjut mengenai preferensi masyarakat Kota Bogor terhadap bus kota. Hal ini menjadi sangat penting karena masyarakat merupakan stakeholder yang utama dalam penentuan kebijakan sistem transportasi. Sinkronosasi kebijakan pemerintah dengan preferensi masyarakat akan menciptakan suatu goal dalam penyediaan transportasi yang efektif dan efisien bagi khalayak umum.

Berdasarkan penelitian kepustakaan variabel-variabel yang diestimasi mempengaruhi utilitas penumpang dalam menggunakan bus kota, yaitu biaya atau tarif, kenyamanan kendaraan, okupansi bus, efisiensi waktu perjalanan, efisiensi waktu tunggu bus, mendapat tempat duduk, kesesuaian perilaku operator bus dengan SOP, safety equipment, efisiensi waktu berjalan kaki dan moda image.

Seluruh variabel tersebut diregresikan dengan metode OLS dan didapatkan model linier dengan persamaan sebagai berikut:

$$
\begin{gathered}
\ln U_{i}=2,637+0,089 \ln X_{1}+0,107 \ln X_{2}+0,148 \ln X_{3}+0,074 \ln X_{4}+0,115 \ln X_{5}+ \\
0,126 \ln X_{6}+0,056 \ln X_{7}+0,079 \ln X_{8}+0,071 \ln X_{9}+0,072 \ln X_{10}+\mathrm{e}_{\mathrm{i}}
\end{gathered}
$$

Keterangan:

$$
\begin{aligned}
& \mathrm{U}_{\mathrm{i}}=\text { Utilitas Penumpang } \\
& \mathrm{X}_{1}=\text { Biaya atau tarif } \\
& \mathrm{X}_{2}=\text { Kenyamanan bus } \\
& \mathrm{X}_{3}=\text { Okupansi bus } \\
& \mathrm{X}_{4}=\text { Efisiensi waktu perjalanan } \\
& \mathrm{X}_{5}=\text { Efisiensi waktu tunggu bus } \\
& \mathrm{e}_{\mathrm{i}}=\text { Error term }
\end{aligned}
$$

$R$-squared dari model ini bernilai 0,86 artinya 86 persen keragaman dari model tersebut dapat dijelaskan oleh variabel-variabel yang terdapat di dalam model, sedangkan 14 persen sisanya dijelaskan oleh variabel-variabel di luar model. Seluruh variabel tersebut signifikan
$\mathrm{X}_{6}=$ Mendapat tempat duduk

$\mathrm{X}_{7}=$ Kesesuaian perilaku operator

bus dengan $S O P$

$\mathrm{X}_{8}=$ Safety equipment

$\mathrm{X}_{9}=$ Efisiensi waktu berjalan kaki

$\mathrm{X}_{10}=$ Moda image

pada taraf nyata 5 persen dan berpengaruh positif terhadap utilitas penggunaan bus kota.

Berdasarkan nilai koefisien terbesar pada persamaan regresi di atas, maka dapat disimpulkan bahwa lima urutan prioritas 
utama konsumen terhadap atribut bus kota yaitu:

1. Okupansi bus (nilai koefisien 0,148 )

Dengan peningkatan okupansi bus sebesar 1 persen maka akan meningkatkan utilitas penumpang sebesar 0, 148 persen, ceteris paribus.

2. Mendapat tempat duduk (nilai koefisien 0,126)

Dengan meningkatnya kesempatan untuk mendapat tempat duduk sebesar 1 persen maka akan meningkatkan utilitas penumpang sebesar 0,126 persen, ceteris paribus.

3. Efisiensi waktu tunggu bus (nilai koefisien 0,115)

Dengan meningkatnya efisiensi waktu untuk menunggu bus sebesar 1 persen maka akan meningkatkan utilitas penumpang sebesar 0,115 persen, ceteris paribus.

4. Kenyamanan bus (nilai koefisien 0,107 )

Dengan kenyamanan bus sebesar 1 persen maka akan meningkatkan utilitas penumpang sebesar 0,107 persen, ceteris paribus.

5. Biaya/tarif (nilai koefisien 0,089)

Dengan adanya penurunan biaya/tarif bus sebesar 1 persen maka akan meningkatkan utilitas penumpang sebesar 0,089 persen, ceteris paribus.

Kelima hasil prioritas konsumen terhadap atribut bus kota di atas akan menjadi modal dasar bagi perencanan transportasi angkutan massal yang berkelanjutan di Kota Bogor. Kelima indikator di atas telah merepresentasikan keinginan penumpang/ pengguna angkutan umum di Kota Bogor.

\section{KESIMPULAN}

1. Gambaran sistem transportasi yang ideal adalah transportasi umum yang massal dan menggunakan bahan bakar minyak secara efisien, oleh karena itu dibutuhkan konversi angkot menjadi bus kota.

2. Berdasarkan hasil regresi model Stated Preference, diperoleh kesimpulan bahwa variabel yang paling diprioritaskan penumpang terhadap atribut bus kota, yaitu okupansi bus, efisiensi waktu tunggu bus, mendapat tempat duduk, kenyamanan bus dan biaya/ tarif. Sehingga rekomendasi yang dapat kami berikan, yaitu masalah kemacetan akibat angkutan umum di Kota Bogor dapat diatasi dengan adanya sarana transportasi massal berupa bus kota.

3. Pemerintah Kota Bogor melalui kelembagaan Badan Layanan Umum (BLU) perlu melakukan revitalisasi Trans Pakuan yang sekarang sdudah ada, malaui penambahan armada dan penambahan trayek Trans Pakuan yang melayani seluruh jalur-jalur protokol di Kota Bogor.

4. Pemerintah Kota Bogor segera memperkuat kelembagaan usaha Trans pakuan Bogor menjadi lebih berdaya melalui pembentukan P.T. Trans Pakuan, sebagai salahsatu Badan Usaha Milik Daerah (BUMD) di kota Bogor yang profesional dan amanah dalam melayani kepentingan transportasi masyarakat Bogor secara umum.

\section{DAFTAR PUSTAKA}

Antara. 2011. Atasi Kemacetan, DLLAJ Kota Bogor Kurangi Jumlah Angkot. http://bisnisjabar.com/index.php/2011/09/atasikemacetan-DLLAJ-kota-Bogor kurangi-jumlah-angkot/ (diakses tanggal 28 September 2011).

Arsyad, L. 1999. Ekonomi Pembangunan. STIE. Yayasan Keluarga Pahlawan, Yogyakarta.

Glasson, J. 1977. Pengantar Perencanaan Regional (Bagian Satu dan Dua). Paul Sitohang [penerjemah](1990). Lembaga Penerbit FE-UI, Jakarta. 
Jhingan, M. L. 2004. Ekonomi Pembangunan dan Perencanaan. PT. Raja Grafindo Persada, Jakarta.

Kuncoro, Mudrajad. 2003. Ekonomi Pembangunan Teori, Masalah, dan Kebijakan. APP AMP YPKN, Yogyakarta.

Mangkoesoebroto G. 2009. Ekonomi Publik. Yogyakarta: BPFE Yogyakarta.

MHM Amirotul, Agustin T, W S Hastuti. 2006. Analisis Variabel Layanan angkutan Umum Bus Kota Menurut Persepsi Penumpang Dengan Teknik Stated Preference (Studi Kasus Angkutan Umum Bus Kota di Surakarta). Media Teknik Sipil. Universitas Sebelas Maret: Fakultas Teknik. Hlm 55-60

Pemerintah Kota Bogor. 2011. Seluruhnya Ada 3.412 Unit Angkot Beroperasi di Kota Bogor. http://kotabogor.go.id/index.php?o ption=com_content\&task=view\&id $=7596$ (diakses tanggal 28 September 2011).

Priyarsono, D.S., Sahara, dan M. Firdaus. 2007. Ekonomi Regional. Universitas Terbuka, Jakarta.

Subandi. 2008. Ekonomi Pembangunan. Alfabeta, Bandung.

Tarigan R. 2005. Ekonomi Regional: Teori dan Aplikasi. Jakarta: Bumi Aksara.

Wahyuningtias E. 2008. Kemacetan di Pusat Kota Bogor [Skripsi]. Depok : FMIPA Universitas Indonesia.

World Bank. 1996. Sustainable Transport: Priorities for Policy Reform. Development in Practice Series.Washington, DC: World Bank.

\section{UCAPAN TERIMAKASIH}

Penulis dalam kesempatan ini mengucapkan terimaksih kepada pihakpihak yang telah mendukung pembuatan jurnal penelitian ini, terutama kepada :
1. Dr. Sri Mulatsih dan Sri Retno W.N, SE, sebagai Pengelola Jurnal Ekonomi dan Kebijakan Pembangunan Fakultas Ekonomi dan Manajemen Institut Pertanian Bogor, yang telah berkenan memublikasikan penelitian ini sebagai bagian dari jurnal ekonomi dan kebijakan pembangunan.

2. Direktur Direktorat Pendidikan Tinggi Kementerian Pendidikan dan Kebudayaan Republik Indonesia, yang telah membiayai penelitian ini.

3. Dr. Rimbawan, Direktur Direktorat Kemahasiswaan Institut Pertanian Bogor, yang telah memfasilitasi terwujudnya penelitian ini.

4. Mahasiswa di lingkungan Program Studi Ekonomi dan Studi Pembangunan yang terutama, kepada Desi Erilia Juanda, Fridayanti Dwi Mumpuni, Vevi Retno Maretha, Farhana Zahrotunisa yang telah terlibat secara langsung dalam proses penelitian ini.

5. Pihak-pihak lain yang tidak dapat disebutkan satu-persatu, yang telah terlibat secara tidak langsung, sehingga terselesaikannya penelitian ini.

Semoga partisipasi dan kontribusi dari yang pihak-pihak yang telah disebutkan di atas, merupakan amal yang baik, dan mendapat balasan dari Allah SWT. 